\title{
UMA ANÁLISE DE IMAGENS DE CAPA DA REVISTA ATUALIDADES PEDAGÓGICAS: POR UMA ESTÉTICA ESCOLAR NA DÉCADA DE 1950 NO BRASIL
}

DOI: http://dx.doi.org/10.1590/2236-3459/58384

\author{
Marcos Villela Pereira \\ Pontifícia Universidade Católica do Rio Grande do Sul, Brasil. \\ Diogo Franco Rios \\ Universidade Federal de Pelotas, Brasil.
}

\begin{abstract}
Resumo
Neste texto se analisam imagens de cotidiano de sala de aula apresentadas nas capas de dois números da Revista Atualidades Pedagógicas publicados em 1955 e 1960. A partir dessas imagens, tomadas como fontes históricas, analisamos o papel que as imagens poderiam cumprir na construção de uma estética escolar associada à valores que estavam vinculados à escola brasileira da década de 1950 no Brasil. Alguns traços dessas tentativas de estetização e sensibilização moral podem ser identificados em representações de salas de aula, uniformes e posturas dos alunos, vestuário de professores e imagens de sala de aula e laboratório, que estavam em crescente valorização nessa época, marcada pelo desenvolvimentismo e pelo espírito modernizador da sociedade brasileira.

Palavras-chave: história da educação, periódicos, estetização, cotidiano escolar, sala de aula.
\end{abstract}

\section{AN ANALYSIS OF JOURNAL ATUALIDADES PEDAGÓGICAS COVER IMAGES: FOR A SCHOOL AESTHETICS IN THE DECADE OF 1950 IN BRAZIL}

\begin{abstract}
This paper analyzes classroom everyday images that appear on the covers of two issues of the Journal Atualidades Pedagógicas published in 1955 and 1960. From these images, taken as historical sources, we analyze the role that images could accomplish the construction of an aesthetic school associated with values that were linked to the Brazilian school of the 50s in Brazil. Some traces of these attempts to aesthetical and moral awareness can be identified in representations of classrooms, uniforms and attitudes of students, teachers clothing and classroom and laboratory images, that was growing appreciation that time, marked by developmental ism and by modernizing spirit of Brazilian society.

Key-words: history of education, journals, anesthetization, school daily life, classroom.
\end{abstract}




\section{UN ANÁLISIS DE IMÁGENES DE PORTADAS DE LA REVISTA \\ ATUALIDADES PEDAGÓGICAS: POR UNA ESTETICA DE LA ESCUELA EN LA DÉCADA DE 1950 EN BRASIL}

\section{Resumen}

Este trabajo analiza imágenes cotidianas de aula que aparecen en las portadas de dos números de la Revista Atualidades Pedagógicas publicados en 1955 y 1960. A partir de estas imágenes, tomadas como fuentes históricas, se analiza el papel que las imágenes podían lograr la construcción de una estética escuela asociada con los valores que estaban vinculados a la escuela brasileña de los años 1950 en Brasil. Algunos rastros de estos intentos de la conciencia estética y moral pueden ser identificados en las representaciones de las aulas, los uniformes y las actitudes de los estudiantes, ropa de los profesores y imágenes de aula y de laboratorio, que estuvo en creciente aprecio en ese tiempo, marcado por el desarrollismo y del espíritu modernizador de la sociedad brasileña.

Palabras-clave: historia de la educación, revistas, estetización, cotidiano escolar, aula.

\section{UNE ANALYSE DE IMAGES DE COUVERTURE DU JOURNAL ATUALIDADES PEDAGÓGICAS: POUR UNE ESTHÉTIQUE D'ÉCOLE DANS LA DÉCENNIE DE 1950 AU BRÉSIL}

\section{Résumé}

Cet article analyse des images de tous les jours qui apparaissent sur les couvertures de deux numéros du Journal Atualidades Pedagógicas publiés en 1955 et 1960. A partir de ces images, prises comme des sources historiques, nous analysons le rôle que les images pouvaient accomplir la construction d'une esthétique école associée à des valeurs qui ont été liés à l'école brésilienne des années 1950 au Brésil. Quelques traces de ces tentatives de prise de conscience esthétique et morale peuvent être identifiés dans les représentations de salles de classe, les uniformes et les attitudes des élèves, les enseignants et les vêtements classe et en laboratoire images, qui a été en croissance satisfaction que le temps, marquées par développementalisme et en modernisant l'esprit de la société brésilienne.

Mots-clé: histoire de l'éducation, journaux, esthétisation, école de la vie quotidienne, classe. 


\section{Um preâmbulo}

praz-nos começar este trabalho ${ }^{1}$ com uma breve anedota, narrativa de um
episódio acontecido. Há alguns anos, quando um de nós ministrava a
disciplina História da Educação no Curso de Pedagogia de uma universidade gaúcha, o Museu de Arte do Rio Grande do Sul - Margs - expôs a obra A primeira missa no Brasil, de Victor Meirelles. A obra, pertencente ao acervo do Museu Nacional de Belas Artes, havia passado por minucioso processo de restauração e cumpria extensa agenda de exibição no país. A tela, de grandes dimensões $(268 \times 356 \mathrm{~cm})$, foi pintada em $1861 \mathrm{e}$ retrata a missa, celebrada em 26 de abril de 1500 pelo padre Henrique de Coimbra ${ }^{2}$.

Dentre as atividades da disciplina foi incluída a visita ao museu e, a partir daí, diversas discussões foram feitas em sala de aula. Após alguns comentários gerais sobre a obra, projetada sua imagem na tela da sala de aula, foi perguntado às alunas se sabiam dizer quando a tela havia sido pintada. Mais do que depressa uma aluna, um tanto afoita e bem disposta a participar, respondeu: "Ué, professor, em 1500". Perguntando à turma se alguém tinha outra opinião, passou-se um bom tempo até que outra aluna dissesse a data correta: 1861. Esse acontecimento suscitou, naquele momento, uma longa discussão sobre as imagens, as diferentes linguagens, as diversas formas de reprodução, seu caráter documental e seu uso como fonte histórica. O episódio ilustra um pouco o modo como as pessoas interagem com as imagens e o valor que atribuem a elas, especialmente quando impregnadas do senso-comum.

Essa condição evidencia a submissão a que, frequentemente, os sujeitos experimentam ao tomar uma imagem com um caráter objetivo, neutro e veraz. A potência de convencimento que as imagens têm deriva, especialmente, do avanço das tecnologias de registro e armazenamento. Via de regra, ainda que essa discussão esteja atravessada por toda a matriz do pensamento crítico, a imagem ainda é tomada como sinônimo de registro verdadeiro de uma situação.

Queremos por em questão, entre outros aspectos, a relação sempre tensa entre o sujeito que observa e o objeto observado. No caso da imagem fotográfica o sujeito que olha tem diante de si uma imagem, ou seja, o objeto que ele observa não é a coisa, mas uma representação dela. O fotógrafo, esse sim, teve diante de si a coisa observada. Dela, capturou certo recorte e, para além das condições objetivas da sua existência, o próprio exercício da linguagem também aporta conteúdo ao objeto fotográfico. Nesse sentido, vale considerar que a imagem faz coincidir dois fluxos de conteúdo: um deles, o primeiro, resulta do conjunto de elementos pertinentes à realidade da coisa representada que se quer dar a ver ou fazer ver. Estão implicados aí elementos objetivos e subjetivos: resulta da imputação de significados e sentidos por parte daquele que produz a imagem. O outro, o segundo, resulta do conjunto de elementos culturais e históricos que perfazem o meio em que a imagem aparece e do conjunto de valores praticados pelo sujeito que observa, que condicionam o modo de ver.

${ }^{1} \mathrm{O}$ presente trabalho se inscreve no âmbito de pesquisa financiada pelo CNPq com bolsa de produtividade de um dos autores. Uma versão reduzida e preliminar foi publicada, em espanhol, na revista Historia de la Educación Latinoamericana, v. 17, n. 25, 2015, p. 163-185.

${ }^{2}$ http://www.mnba.gov.br. Acesso em 13 fev. 2013. 
Desses aspectos todos nos importa dar destaque àqueles que consideramos como estetizantes. Dispositivos de estetização presentes nas imagens, ou seja, aspectos que, de alguma forma, têm a capacidade de produzir efeitos estéticos sobre os sujeitos observadores. Trata-se de buscar identificar elementos que, de algum modo, podem interferir na formação da sensibilidade, na produção de certo modo de ser. Dentre as inúmeras fontes em que esse tipo de estudo é possível, dentre os diferentes contextos em que essas análise podem ser aplicadas e empregadas, e dentre os distintos caminhos de análise desses elementos, este trabalho se propõe a analisar duas imagens publicadas na Revista Atualidades Pedagógicas de modo a identificar elementos que contribuem para a produção de certa estética juvenil escolar.

Reflexões dessa natureza dialogam bem com a historiografia brasileira que, nas últimas décadas, passou a utilizar a imprensa periódica de modo mais frequente em suas produções. Em função de mudanças teórico-metodológicas mobilizadas pela Nova História, acabou-se por ampliar os tipos de fontes e os problemas que deveriam ou poderiam ser atendidos pelo trabalho do historiador (Luca, 2008), passando a imagem a ocupar um lugar significativo nas pesquisas.

De modo semelhante, a História da Educação também utiliza mais frequentemente os periódicos, por reconhecer o potencial explicativo desse tipo de documento e em função da amplitude dos problemas que vem se permitindo esclarecer. Segundo Bastos (1997),

a imprensa pedagógica - instrumento privilegiado para a construção do conhecimento, constitui-se em um guia prático do cotidiano educacional e escolar, permitindo ao pesquisador estudar o pensamento pedagógico de um determinado setor ou grupo social, a partir da análise do discurso veiculado e a ressonância dos temas debatidos, dentro e fora do universo escolar. Prescrevendo determinadas práticas, valores e normas de conduta, construindo e elaborando representações do social, a imprensa pedagógica afigura-se como fonte privilegiada de estudo: jornais, boletins, revistas magazines; feita por professores para professores, feita para alunos por seus pares ou professores, feita pelo Estado ou outras instituições como sindicatos, partido, associações e lgreja. Sua análise possibilita avaliar a política das organizações, as preocupações sociais, os antagonismos e as filiações ideológicas, as práticas educativas e escolares. (p. 173)

A análise de documentos dessa natureza tem ocupado um importante grupo de pesquisadores, no Brasil e no exterior (Catani; Bastos, 1997), aos quais nos juntamos, com o objetivo de explicar o comprometimento da Atualidades Pedagógicas com uma estetização da escola brasileira nos anos cinquenta, como discutiremos nos itens a seguir.

\section{A Revista Atualidades Pedagógicas}

A Revista Atualidades Pedagógicas foi fundada em 1950 e publicada até 1962. Foi uma iniciativa da Companhia Editora Nacional, editora brasileira fundada em 1925 por Monteiro Lobato e Octalles Marcondes Ferreira. Dentre os 1.192 .000 exemplares 
publicados pela editora em 1933, por exemplo, 467 mil são títulos educacionais, 429.500 são livros infantis, 90 mil de Monteiro Lobato, e 107 mil de literatura em geral (Hallewell, 2005, p. 354).

Em 1932 a Companhia Editora Nacional incorporou a Editora Civilização Brasileira e, em 1934, a marca Nacional se reserva, principalmente, para livros didáticos e infantis. Por volta de 1938 são abertas coleções como a Terra, mar e ar, publicando aventuras que incluíam toda a série de Tarzan, de Edgar Rice Burroughs, a coleção Para todos, a Série negra, de títulos policiais, e a célebre Biblioteca das moças.

Acolhendo sugestões do professor Fernando de Azevedo, a editora se dedicou a uma "larga ofensiva cultural sobre quatro frentes: as crianças, os estudantes dos cursos primários, secundários, profissionais e superiores, os professores de todos os graus de ensino, o público extra-escolar" (Revista Atualidades Pedagógicas, 1950, n. 1, contracapa). Tal ofensiva se processou sob uma bandeira, a da Biblioteca Pedagógica Brasileira. Essas frentes pretendem ser atendidas pelas séries Literatura Infantil, Livros Didáticos, Atualidades Pedagógicas e Iniciação Científica (Revista Atualidades Pedagógicas, 1950, n. 1, contra-capa). A Brasiliana foi a quinta série da Biblioteca Pedagógica Brasileira, lançada pouco depois da Revolução de 1930 e da criação do Ministério da Educação, tendo sido dirigida até 1955 por Fernando de Azevedo ${ }^{3}$. Essa última série é considerada "a mais vasta e completa coleção e sistematização de estudos brasileiros" (Revista Atualidades Pedagógicas, 1950, n. 1, contra-capa) e é uma referência em termos de qualidade, para a editora.

Em 1948 Énio Silveira assumiu a direção da editora, instituindo significativas mudanças na linha editorial e na área gráfica, com a introdução de ilustrações nas capas e no interior dos livros e o uso da brochura como estratégia de popularização das obras. Ao longo dessa década, acompanhando o crescimento do ensino secundário, a expansão do número de ginásios e a criação de novas escolas em todo o país, a editora se tornou uma das maiores do Brasil. Em janeiro de 1950 foi publicado o primeiro número da Revista Atualidades Pedagógicas, apresentada como "veículo de divulgação dos educadores brasileiros" (Revista Atualidades Pedagógicas, 1950, n. 1, p. 1), assumindo como público principal os professores do ensino secundário. Procurando seguir o parâmetro da série Brasiliana, a série Atualidades Pedagógicas, então coordenada pelo professor J. B. Damasco Penna, publicou

obras escritas especialmente em português ou traduzidas de qualquer outra língua sôbre biologia educacional, higiene escolar, psicologia aplicada à educação, sociologia educacional, didática, administração escolar e, em suma, sôbre as bases científicas e os problemas gerais e particulares da educação. [...] Essa revista, que the tomou o nome, pretende seguir-Ihe o espírito. (Revista Atualidades Pedagógicas, 1950, n. 1, contra-capa)

Ênio Silveira, diretor-responsável e editor da revista, junto com Ary da Matta, entre 1950 e 1959, a caracterizava como uma revista "a serviço da unidade nacional tomando a educação como denominador comum desta mesma unidade solicitada" (Revista Atualidades Pedagógicas, 1950, n. 1, p. 1):

${ }^{3}$ http://www.brasiliana.com.br/brasiliana/colecao. Acesso em 13 fev. 2013. 
Atualidades Pedagógicas, veículo de divulgação dos educadores brasileiros, será um espelho das aspirações, das experiências, dos anseios da escola brasileira reivindicando para si o lema de bem servir e bem informar a quantos, nos setores do poder público ou da iniciativa privada, se incluem entre os lavradores dos campos da educação e do ensino em nossa terra. Não se trata de uma revista de doutrina, de técnicas, de processos ou de ciência educacionais. Para bem servir e bem informar Atualidades Pedagógicas se coloca no plano da boa divulgação abrigando, em suas páginas, a palavra do pesquisador e do especialista, do teórico da educação, a do que concluiu uma experiência objetiva.

Ainda com relação ao primeiro número é importante mencionar que a primeira matéria assinada, no corpo da revista, são os "resultados do Seminário Inter-americano de alfabetização e educação de adultos", de autoria de Lourenço Filho (Revista Atualidades Pedagógicas, 1950, n. 1, p. 3).

A revista circulou de janeiro de 1950 a dezembro de 1962, tendo sido publicados 53 números, dos quais tivemos acesso a 50, pertencentes ao acervo da PUCRS ${ }^{4}$, sendo distribuídos para escolas, instituições de ensino e professores.

Para agregar uma informação adicional vale mencionar que Ênio Silveira, em 1965, criou a revista Civilização Brasileira, marco do pensamento político e cultural de resistência à ditadura militar, fechada após o Ato Institucional n. 5, em de 1968. Ele mesmo, devido à sua vinculação ao PCB e pela publicação de obras de Karl Marx e Antonio Gramsci, foi preso sete vezes durante esse período ${ }^{5}$. Em 1980, a Companhia Editora Nacional foi incorporada pelo Instituto Brasileiro de Edições Pedagógicas - Ibep -, constituindo um dos maiores grupos editoriais do Brasil (Hallewell, 2005).

\section{As capas}

Das 50 capas a que tivemos acesso 32 delas trazem estampada a imagem de alguma instituição de ensino, das quais trinta são fotografias de prédios - fachada, vista aérea ou detalhe - e duas são fotografias de maquetes. Duas retratam monumentos públicos: o monumento à Independência, em São Paulo, SP, e o Palácio da Alvorada, em Brasília, DF. Uma retrata o interior das oficinas gráficas de uma editora paulista e uma traz um instantâneo da inauguração de uma livraria. Uma retrata uma cerimônia - um ato solene em um congresso de educação, com a presença de autoridades - e duas trazem a fotografia de educadores ilustres: Lucia de Magalhães e Martim Damy. Onze retratam alunos e alunas: quatro representam situações de ensino, três trazem uma aluna em frente à instituição, duas trazem um grupo de estudantes em frente à escola, uma registra um grupo de alunos na biblioteca e uma registra uma aluna recebendo a doação de livros.

Para este trabalho elegemos analisar duas capas que trazem a imagem de grupos de jovens estudantes em situações cotidianas, em que também figuram professoras em exercício docente no interior de salas de aula. Em cada uma delas o modelo de prática docente é distinto e sua caracterização será apresentada mais adiante. Escolhemos tais

\footnotetext{
${ }^{4}$ As revistas consultadas fazem parte do acervo da Biblioteca Central Irmão José Otão, da Pontifícia Universidade Católica do Rio Grande do Sul, na coleção Acervo histórico, organizadas em seis volumes, encadernadas por ordem cronológica de publicação. Elas se encontram em bom estado geral, com pequenos cortes na margem direita de algumas páginas e capas, provavelmente feitos durante 0 processo de encadernação nos tomos. Os cortes não chegam a causar perda de conteúdo.

$<$ http://www.itaucultural.org.br/aplicexternas/enciclopedia lit/index.cfm?fuseaction=biografias texto\&cd verbete=9348 $>$. Acesso em 13 fev. 2013. \begin{tabular}{|l|l} 
Hist. Educ. (Online) & Porto Alegre
\end{tabular} v. 20 ก. 49 Maio/ago., 2016 p. $187-208$
} 
capas com vistas a analisar alguns aspectos didáticos, históricos e estéticos que sugerem um modo singular na relação professor e alunos e destes com o conteúdo e o processo de aprendizagem.

As capas a serem analisadas serão a do número 31, publicado em 1955, cuja imagem retrata o cotidiano escolar em aula de geografia e é referenciada como Colégio estadual (Sergipe), e a do número 51, publicado em 1960, cuja imagem registra o cotidiano escolar em um laboratório de ensino de ciências e é referenciada como Uso do material didático no ensino da matemática.

Nos primeiros números da revista aparece o nome de Manoel Victor Azevedo Filho como responsável pelas ilustrações. Importante ilustrador, trabalhou boa parte de sua carreira na Companhia Editora Nacional, tendo sido responsável pelas ilustrações da obra de Monteiro Lobato. Na revista foi responsável pelas vinhetas e ilustrações. Durante toda a existência da Atualidades Pedagógicas aparecem os nomes de Theobaldo de Nigris e Rubens de Barros Lima como responsáveis pela parte gráfica. O primeiro, Theobaldo de Nigris, foi um nome consagrado na história das artes gráficas no Brasil. O segundo, Rubens de Barros Lima, foi um dos editores da Companhia Editora Nacional, tendo sido responsável por toda a política de editoria gráfica da editora dos anos 1940 até os anos 1970. As fotografias utilizadas na revista, no entanto, não têm identificação do autor. $A$ maioria delas tem alguma legenda descritiva da situação, do local ou dos sujeitos nela representados. Muito raramente, no corpo dos textos, aparece alguma menção às condições de registro das imagens. No caso das capas isso não é diferente. Logo abaixo do título e acima da fotografia aparece uma legenda identificando o nome da instituição, sujeitos ou situação retratada na imagem. Todas são em preto-e-branco.

\section{Sobre estética e estetização}

A escola, em sua forma moderna, talvez seja o principal dispositivo civilizatório que conhecemos. O mais potente, o mais poderoso e o mais abrangente, haja vista a sua universalização a partir da obrigatoriedade de escolarização que se disseminou ao longo do século 20. Ao lado do cumprimento das tarefas curriculares pertinentes à instrução, compete à escola oferecer uma série de parâmetros para a formação geral do sujeito. Essa formação passa pelo desenvolvimento de princípios morais, pela adoção de valores, pela experimentação de processos de socialização, pela formação da sensibilidade e pelo desenvolvimento do gosto. De modo geral, poderíamos dizer que a escola, a partir da modernidade, traz para si a tarefa de formar ética e esteticamente o sujeito, fornecendoIhe arsenais de argumentos e estratégias para que ele seja capaz de exercitar julgamentos de toda ordem em seu cotidiano.

De certo modo, podemos afirmar que a tarefa da educação escolar é proporcionar condições para que o sujeito conheça o mundo e aja sobre si mesmo de maneira a dirigir sua própria existência. O projeto civilizatório da escola moderna é moldado pela perspectiva da harmonia social, onde o todos é o parâmetro para o cada um, ou seja, o padrão da cortesia, da conduta correta e adequada da corte, aos poucos vai sendo transformado no ideal de civilidade:

A vida coletiva na cidade vai sendo arranjada segundo os princípios da gentileza e a educação escolar vai tomando para si a tarefa de formar não apenas o intelecto dos sujeitos, mas, igualmente, sua sensibilidade. O 
sujeito escolarizado deverá ser capaz de julgar e tomar decisões sobre sua vida de modo que o mundo se torne cada vez melhor para todos. Havemos de ser bons não porque seja prazeroso, agradável ou conveniente, mas porque é moral: devemos ser bons. A sensibilidade é a base estética de uma nova forma de ser em sociedade, contribuindo para a autorregulação do sujeito em sua jornada em busca do consenso. A sensibilidade é o parâmetro de autorreferência que fará as vezes de mecanismo de coerção e controle, agora internalizados pelo sujeito. A estética e a sensibilidade passam a operar como uma espécie de prótese da razão, ajudando a razão a alcançar níveis e dimensões que sozinha não conseguiria. (Pereira, 2012a, p. 40)

Os julgamentos bonito-feio são aproximados e identificados de forma drástica dos julgamentos bem-mal; ser belo e bonito é praticamente sinônimo de fazer o bem e ser bom. A formação do sujeito será conduzida de maneira que a amorosidade, a afeição e a sensibilidade sejam argumento para sua adesão ao imperativo da lei, das obrigações e dos deveres. Os bons alunos serão aqueles que, às custas da promessa de um elogio ou um prêmio na ordem do afeto, cumprirem adequadamente as tarefas e obedecerem as determinações das regras. Do mesmo modo, valores como a higiene, limpeza, proporcionalidade e ordem são propalados como indicadores de uma ética e uma estética ideais. A sensibilização moral representa um efeito da estetização da vida que move, simultaneamente, uma força emancipatória e uma repressão interna. Eagleton nos diz "que o estético não é outra coisa que outro nome para o inconsciente político: o sujeito internaliza códigos e convicções que o governam como se fossem a fonte da sua própria autonomia" (1993, p. 21). A moral se converte em estilo de vida e os modos e os costumes operam como indicadores de conduta, pensamento e juízo. A educação terá por objetivo municiar o indivíduo de modo que ele modele a si mesmo como se esse movimento acontecesse de dentro para fora, pois, ao incorporar o conteúdo dos valores e princípios, ele aprende a operar sua sensibilidade nos moldes da razão formal e, quando acredita estar forjando sua intimidade ou desenvolvendo sua consciência, está colocando em funcionamento seus juízos, afetos e respostas corporais segundo uma lei que não é propriamente uma lei. A moral se converte em rotina e a condução supostamente segura de seus hábitos e julgamentos atende à demanda do enraizamento de uma certa forma da razão prática, de uma ética com pretensões à universalidade, de uma estética generalizada (Pereira, 2012b).

Estamos entendendo que a escola é uma máquina estetizante porque é uma poderosa agência de subjetivação. Ao subjetivar o sujeito, ela o emancipa e o sujeita, ao mesmo tempo. E o faz segundo um modelo que busca dar conta de executar o projeto civilizatório moderno que modela a razão e a sensibilidade segundo um ideal sempre abstrato e externo a si mesmo. E essa exterioridade é uma condenação do sujeito a um desejo permanente de universalização, de eternidade e de perfeição (Pereira, 2012a, p. 51).

\section{A análise da imagem}

São inúmeros os estudos existentes sobre análise de imagens. Importantes pesquisas vêm sendo desenvolvidas no campo documental (Smit, 1997; Manini, 2002), da arte (Berger, 1999; Francastel, 1983), da estética (Joly, 1996; Barthes, 1984), da comunicação (Kossoy, 1980; Maranhão, 1988; Coutinho, 2006), da semiótica (Arfuch, 
2006; Souza, 2001), da história (Paiva, 2006; Burke, 2004), dos estudos visuais (Neiva Jr., 1986; Martín-Barbero e Rey, 2001). Não é nossa pretensão, aqui, esgotar esse manancial de concepções ou fazer a exegese dos métodos de análise. Faremos um recorte intencional, delineando um caminho que consideramos adequado à discussão que pretendemos trazer à tona, sem prescindir ou desprezar os demais percursos possíveis. De forma deliberada, nos ativemos às referências sobre a análise de imagens, sem, no entanto, nos dedicarmos à particularidade da fotografia como recurso ou linguagem. Nossa escolha deriva do fato de que a pretensão da análise que ora apresentamos é ensaiar alguns aspectos acerca da estetização da escola. Os estudos específicos sobre a fotografia não serão tomados em virtude do fato de estarmos interessados no conteúdo das imagens, e não em sua forma de expressão ${ }^{6}$. Para tanto, tentaremos apresentar argumentos que contribuam para evidenciar a consistência de nossa escolha.

Estamos entendendo que cada fotografia representa um instantâneo e um recorte de um fato ou situação. A imagem fotográfica é um campo de convergência de contextos, significados e sentidos existentes no âmbito da experiência de quem a produz e de quem a contempla. Dessa forma, podemos dizer que a fotografia é uma forma de construção da realidade e, por isso, afeita a interpretações e interferências subjetivas. As fotografias, mesmo quando tratadas como documentos, não têm identidade direta com a realidade objetiva que representam, mas, mais que isso, resultam e provocam certa forma de olhar: "nenhuma imagem é estável ou passível de assegurar uma representação fixa ou certa" (Martins, 2007, p. 30).

Uma imagem é sempre polissêmica e sua análise tende a potencializar essa polissemia no imaginário de seu analisador, mas pretendemos fazer um recorte inicial e exercitar uma análise que privilegie os elementos estéticos e estetizantes nelas presentes. Consideramos que há uma intencionalidade nas imagens para, por um lado, mostrar um conjunto de indicadores de uma determinada estética: traços da época, indícios que o autor da imagem e o editor da revista pretendem dar a ver e fazer ver. Por outro lado, indiscutivelmente aderidos ao espírito de modernização que caracteriza os anos 1950, autor e editor também estão preocupados em fornecer elementos para que o observador seja afetado por certo estilo que se pretende propagar. Porém, vale uma advertência: não faremos nenhuma análise em termos da recepção ou do endereçamento (Ellsworth, 2001).

As imagens escolhidas também têm uma característica comum: elas estão fundadas na pose. Mesmo aquelas que parecem registrar situações descontraídas ou espontâneas, todas sugerem que houve intencionalidade e preparação ${ }^{7}$. Essa construção intencional contribui para induzir nosso olhar a ver algo que "o nosso exercício diário de observação não foi capaz de ver" (Neiva Jr., 1986, p. 63). Por vezes, nesses casos, a função da fotografia é tão somente fazer ver algo que escapa ao olhar cotidiano; por vezes, trata-se de impor certa construção, nos moldes da fabricação de um simulacro da realidade que se quer representar, induzindo o observador a fazer um determinado juízo. Por vezes, ainda, a função da imagem é o oposto de si mesma, ou seja, é mostrar algo de forma a impedir que se veja o que não se quer que seja visto. Enfim, a tarefa da interpretação vai

\footnotetext{
${ }^{6}$ Para aprofundar estudos sobre fotografia e história, consultar Carvalho (1994); Carvalho; Lima (2000); Leite (1993); Mauad (1990, 1996, 2015); Monteiro (2012).

7 Para aprofundar estudos sobre essa tendência consultar Barthes (1984). 
sempre exigir que aquele que interpreta se confronte com seus próprios parâmetros de interpretação, forçando as perguntas o que vejo? Por que vejo o que vejo? Como vejo o que vejo? Por que vejo do modo que vejo? Nesse sentido é que procuramos, de antemão, assumir essa abordagem relativa à estética e à estetização, de maneira a deixar claro para o nosso leitor também nossa intencionalidade.

No que se refere ao campo da História, Burke (2004) reconhece que, para o historiador, o problema da interpretação das imagens e as análises possibilitadas por elas não são uma peculiaridade desse tipo de fonte e apresenta uma síntese de questões que considera importantes para a utilização das imagens como fonte de pesquisa. Dessas, destacamos o fato das imagens não darem acesso ao mundo social diretamente, mas a visões que eram contemporâneas quando de sua produção, que as imagens pertencem e expressam uma série de aspectos socioculturais e de interesses que estão por trás de sua produção. Portanto, o historiador não pode se abster de sua responsabilidade de leitura das entrelinhas e dos indícios que podem ajudar a elucidar traços relacionados aos significados, conscientes ou não, que o fotógrafo quis imprimir na imagem.

Por fim, antes de procedermos nosso exercício de análise, vale por em destaque mais um limite. A análise das imagens será feita mediante o uso da linguagem verbal. Portanto, é bastante provável que se produza uma tensão entre essas duas esferas de linguagem, cada uma com seu estatuto, sua gramática e sua sintaxe. Usaremos as palavras para fazer ver o que vemos e, portanto, estaremos à mercê também do "imperialismo da língua" (Coutinho, 2006, p. 334), capturados pelo espaço tensionado entre esses dois universos.

Conforme nos repete Coutinho (2006), "é preciso estabelecer um percurso que envolva algumas etapas ou procedimentos metodológicos" (p. 334). A autora propõe um percurso articulado em três etapas: a leitura: descrição; a interpretação ou análise e a síntese ou conclusão. Smit (1997), por sua vez, propõe uma categorização feita em três parâmetros, orientados por três perguntas: o que a fotografia mostra?: o conteúdo informacional da imagem; como a fotografia mostra?: a forma usada para mostrar o conteúdo; e onde a fotografia mostra?: o meio no qual a fotografia aparece (Smit, 1997). Seguiremos as etapas propostas por Coutinho (2006), entremeando com os parâmetros propostos por Smit (1997).

Responder à última questão de Smit (1997) nos parece bem mais do que indicar onde podem ser localizadas tais fotografias: para o que, no caso que estamos analisando aqui, serviria uma indicação geral para todas as imagens, já que estamos tomando em análise imagens apresentadas apenas na Revista Atualidades Pedagógicas, já contextualizada na primeira parte deste trabalho. Entretanto, refletir a respeito de onde está publicada ou o meio no qual a fotografia aparece pode levar a interpretar que, ao selecionar as imagens que comporiam as capas da Atualidades Pedagógicas, havia uma intenção de que a imagem escolhida pudesse servir de modelo ou referência para as demais escolas. Ao mostrar a escola que se deseja ver representada nas cenas publicadas, construía-se o que, na perspectiva dos editores, poderia ser um padrão exemplar para ver e ser visto.

Assim, a última questão proposta por Smit (1997) talvez seja aquela que mais se associa ao debate que estamos tratando aqui: o meio no qual aquelas imagens escolares apareciam e figuravam com destaque na capa se pretendia veículo de ampla circulação 
para disseminar uma estética escolar que se via ou se pretendia ver nas escolas brasileiras. Ao produzir e compor certa identidade juvenil escolar e fazê-la fixar-se nas capas de uma revista de tal importância, esse meio onde a fotografia aparece já é um indício do esforço em defesa de certo padrão de beleza, correção, um adequado padrão juvenil educado que deveria e merecia circular pelo país, servindo de modelo à organização escolar e aos grupos juvenis a ela vinculados. É a partir da leitura dessas fotos-emblema (Barros, 1989) que se pode identificar a proposição e a defesa de padrões escolares a serem construídos nas instituições de ensino espalhadas pelo país.

Nesse caso, pode-se entender que a autoridade atribuída à revista, em função do papel que desempenhou na formação e orientação dos professores à época, também derivava das capas, conferindo-Ihes também um caráter de orientação quanto ao que viria a ser a estética da juventude educada do país.

A etapa da leitura será feita de forma articulada com a interpretação, já que não acreditamos na possibilidade de uma leitura que já não carregue em si os traços analíticos daquele que lê. A leitura já é uma interpretação. Procuraremos apresentar uma descrição da imagem, destacando seu conteúdo sob os aspectos do enquadramento, composição, relação figura/fundo e sentido da imagem. Nessa etapa procuraremos evidenciar o que se deixa ver e o modo como é dado a ver. Estaremos tomando os elementos da composição e do enquadramento como uma espécie de gramática da imagem (Coutinho, 2006), buscando analisar o quanto e o que foi dado a ver. Já a relação figura/fundo será analisada de modo a identificar a hierarquia dos elementos - primeiro plano, segundo plano, plano de fundo -, buscando explorar as componentes indicadores de valor, importância, destaque, etc. Por fim, quanto ao sentido da imagem, trataremos de inferir elementos que julgarmos significativos das ações estética e estetizadora, pertinentes aos aspectos históricos e ideológicos que cada imagem carrega.

\section{Análise das imagens}

Começaremos analisando uma capa cuja imagem remete ao Colégio Estadual de Sergipe. 
Figura 1 -

Capa da Revista Atualidades Pedagógicas, ano VI, n. 31, 1955.

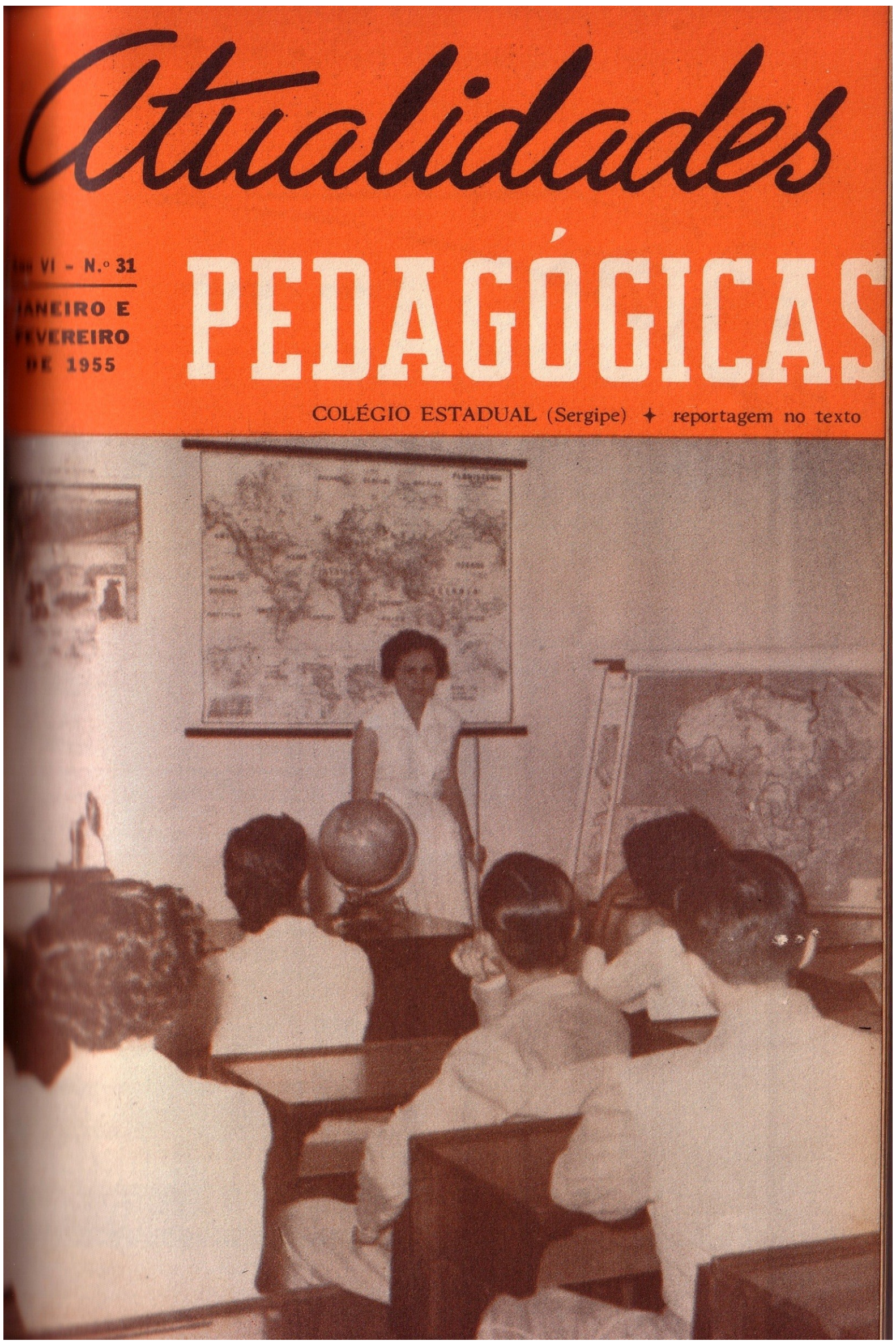


A imagem referida como Colégio estadual (Sergipe) mostra o interior de uma sala de aula, tomada desde uma diagonal que parte do fundo, à esquerda. A professora está em pé, atrás de sua mesa e à frente de um mapa-múndi que está pendurado na parede, de frente para os alunos e para a objetiva. Sobre a mesa, à sua frente, há um globo terrestre e ao seu lado esquerdo há um dispositivo com mapas sobrepostos, dos quais se vê o mapa da África. Ela tem na mão esquerda, provavelmente apoiado no chão, um apontador: vara longa de madeira utilizada para apontar, à distância, à maneira de demonstração ou indicação. Podemos começar analisando o que não aparece na fotografia: não se vê, na sala de aula, um quadro-de-giz. A ausência desse recurso está patente na imagem, já que não se trata de um mapa posto na frente dele, ele não está oculto. Essa imagem sugere algo a partir daquilo que não mostra: nessa situação, a professora não tem onde escrever ou desenhar, mas apenas o que e com o quê apontar e indicar. Nota-se que ela provavelmente apresenta o conteúdo, o mundo, de uma forma que corresponde, razoavelmente, à modernização tecnicista do modo tradicional de ensinar Geografia, que se pautava na memorização e na classificação (Castrogiovanni, 2000).

A imagem não sugere nenhum traço das mudanças que seriam introduzidas no final dos anos 1970, com a chamada Geografia Crítica. Tão-somente sugere a utilização de recursos que, ainda sem alterar a centralidade do conteúdo, tornam a aprendizagem mais atraente para o aluno. Associada à ausência do quadro-de-giz pode-se observar a presença dos mapas arranjados em uma espécie de álbum seriado: além do globo e do mapa-múndi que está exposto na parede ao fundo, vemos, à direita da imagem, um conjunto de mapas sobrepostos - vê-se o continente africano e supõe-se que os outros mostram outros continentes - , disposto em um cavalete ou suporte similar que permite folheá-los, viabilizando uma aula mais dinâmica do que a exposição estática de cada mapa, um por vez, na parede. A simultaneidade da exposição - o mapa-múndi na parede, o globo sobre a mesa e o mapa dos continentes ao lado - sugere uma metodologia mais ágil para a apresentação do conteúdo. Mas a disposição das carteiras, a seriedade e sisudez do ambiente e a distância entre os alunos e aqueles objetos sugerem que, em essência, ainda predomina a abordagem tradicional.

A professora usa um vestido branco sem muitos detalhes, com mangas cavadas e gola em $v$ e seus braços acompanham a linha do corpo, em posição relaxada. Os cabelos são curtos e com pouco volume, arrumados com simplicidade. Apesar dela compor o plano de fundo da imagem, ela está bem no centro da fotografia, indicando dessa forma o seu protagonismo na cena. Não se vê, na imagem, se ela carrega outro material de apoio - caderno, anotações ou livro didático - o que também contribui para induzir um entendimento da professora como alguém que sabe, alguém que já memorizou o que deve ser transmitido, e o conteúdo, supostamente, emerge dos meios e recursos habilmente manipulados por ela. A imagem ajuda a construir um emblema do tecnicismo pedagógico que caracterizou o ensino escolar brasileiro entre as décadas de 1950 e 1970, reforçando a ideia da centralidade do conteúdo e a aparente neutralidade do professor.

$\mathrm{Na}$ assistência veem-se cinco alunos de costas, em carteiras de madeira muito bem alinhadas, com o tampo inclinado e o assento conjugado. Observa-se que são três moças e dois rapazes. As moças estão usando camisa branca, provavelmente uniformes, e usam 
os cabelos curtos. Os rapazes vestem-se com muita formalidade, usando calça e casaco, cabelos curtos com orelhas descobertas e nuca à mostra, com fixador. Todos estão de costas, aparentemente concentrados na professora: destaque-se o aluno bem ao centro da imagem, com a mão no queixo. A atmosfera formal sugere uma estética bastante sisuda, com pouca diferenciação entre o jovem e o adulto. O tipo de vestimenta - o uniforme ou o terno - são dispositivos que contribuem para a neutralização da singularidade dos sujeitos: na fotografia, nesse aspecto, há muita semelhança entre a caracterização da professora e dos estudantes. O que ressalta é mais a diferença de gênero do que a diferença entre grupos geracionais ou funcionais.

Outro aspecto que merece menção é o fato das carteiras estarem vazias: nenhum dos estudantes traz caderno, livro ou qualquer tipo de material para registro. Não há indícios de apropriação instrumental do conteúdo que não seja pela via da indicação, demonstração e memorização. Parece-nos que essa é uma escola que opera a transmissão do conteúdo, do professor para o aluno, mas que encontra substrato nos meios e aparatos técnicos de armazenamento e manejo das informações.

Que escola pretende ser mostrada nessa imagem? Trata-se, a nosso ver, de uma escola pouco individualizada. Uma escola ancorada em procedimentos que podem ser levados a efeito por qualquer sujeito que maneje e opere de forma adequada certos instrumentos e meios. Uma escola em que o sujeito-professor fica quase invisível ante um aparato técnico que contém e media o acesso ao conteúdo programático. O mundo moderno toma vulto, a sociedade se espelha no modo bem sucedido da vida do típico cidadão norte-americano mediano, e a escola adere a essa progressiva estilização da vida cotidiana. Assim como as donas-de-casa aprendem a manejar com destreza os objetos e aparelhos que supostamente facilitam seu dia-a-dia - batedeiras, enceradeiras, máquinas de lavar, a comida instantânea - os professores devem aprender a manejar dispositivos que, analogamente, vão facilitar seu cotidiano didático. O conteúdo programático, em certa medida, fica subsumido ao meio pelo qual será apresentado e transmitido, sugerindo uma forma de estetização superficial da matéria escolar (Welsch, 1995).

E que concepção de estética juvenil está sendo celebrada? Observa-se que aquela atmosfera de seriedade e sisudez, combinada com o clima de atenção e concentração, contribuem com certa indiferenciação entre o jovem e o adulto. Todos são sujeitos de uma sociedade em desenvolvimento que começa a aderir ao espírito do progresso característico dos anos $\mathrm{JK}^{8}$, que estão por iniciar. $\mathrm{O}$ estilo ainda faz parte do cotidiano sob a forma de modelização, não ainda como evidência de um traço singular do sujeito. Predominam padrões de gênero que, à época, estão sobrepostos às diferenças de classe, geração ou função e ainda não é possível vislumbrar os traços da celebração mais vigorosa da juventude que se iniciará de forma mais evidente nos anos seguintes.

A seguir, vamos analisar a capa cuja imagem remete ao uso de materiais didáticos para o ensino de matemática.

${ }^{8}$ Os anos JK correspondem ao período de governo de Juscelino Kubitscheck de Oliveira, entre 1956 e 1961, caracterizado por tendência progressista. Seu lema foi 50 anos em 5. 
Figura 2 -

Capa da Revista Atualidades Pedagógicas, ano XI, n. 51, 1960.

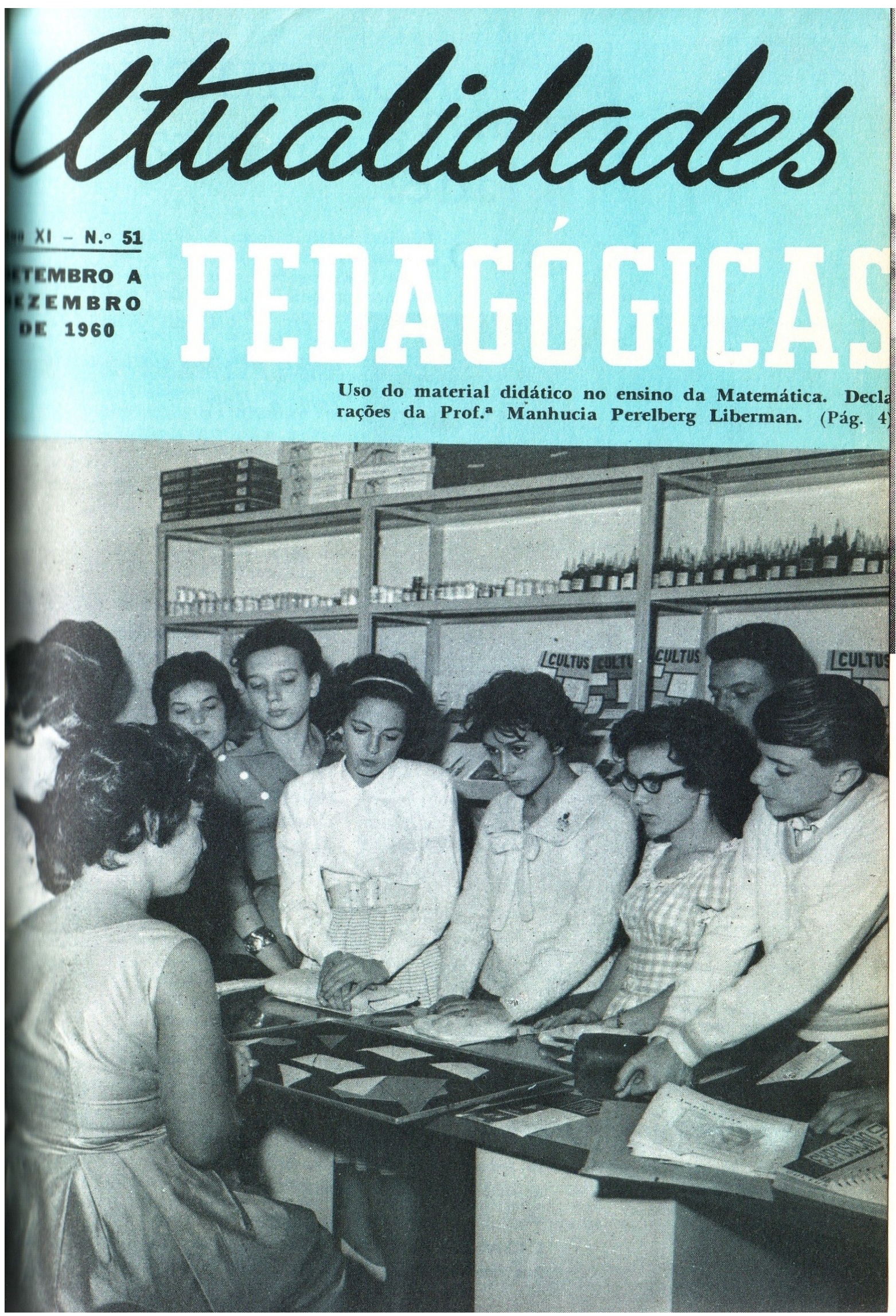


A imagem, referida como Uso do material didático no ensino da matemática, apresenta uma cena tomada durante uma atividade acontecendo em um laboratório. Ao fundo vê-se uma estante articulada em três módulos, contendo o que parecem ser frascos de reagentes e substâncias químicas e, em uma das prateleiras, dispostas em pé e de modo que fiquem com a capa visível, exemplares da Revista Cultus, uma revista dedicada ao ensino de ciências ${ }^{9}$, editada pelo Funbec (Nardi, 2007). Tudo isso feito sobre um balcão, provavelmente coberto com vidro, como se nota pelo reflexo da pulseira da aluna à esquerda. À frente da professora há uma prancha com formas geométricas. As formas claras, misturadas às escuras, sugerem que seja um tangram. Oobserva-se que provavelmente o folheto - à direita - seja um conjunto de instruções de uso desse jogo.

A identificação do laboratório, a apresentação da Revista Cultus e o uso de materiais manipuláveis são uma evidente marca da escola experimental, sugerindo-se que é possível experimentar também em aulas de Matemática. Por exemplo, podemos tomar a pose da professora, uma atitude de espera, como quem dá oportunidade aos alunos para pensarem e experimentarem, ou seja, o uso de laboratório está articulado com as aulas de ciências naturais - observamos os frascos na prateleira, um livro sobre exposições mas não se esgota nessas disciplinas. Parece-nos um modelo de escola que adere ao moderno, sugerindo como poderiam ou deveriam ser as atividades extraclasse ou de uso de laboratório.

Conforme já analisado em outro trabalho, podemos supor que

os alunos estariam se preparando direto para a formação que teriam na universidade, interpretação que se ajusta bem, por exemplo, com os objetivos associados à ampliação da carga-horária das disciplinas de ciências experimentais [...] esses objetivos passaram a ser esperados do ensino de ciências experimentais a partir da Lei $n^{\circ} 4.024 / 61$, que aumentou substancialmente a carga horária dessas disciplinas no colegial. Essa medida também estava em consonância com os interesses políticos nacionais para os quais parecia estratégico aumentar o peso das disciplinas de ciências experimentais e matemática no nível secundário no país, acompanhando uma tendência internacional. (Rios, 2012, p. 70) $)^{10}$

Agrupados ao redor da bancada estão nove jovens e uma professora. Essa última está de costas, em meio perfil, sentada. Todos os outros estão em pé. Ela tem os cabelos curtos e usa um vestido com cintura ajustada, mangas cavadas, com decote redondo, também cavado, que lhe deixa ver o começo das costas. Como já mencionamos, sua atitude - sentada, com as mãos cruzadas - sugere uma postura de espera. Ao mesmo tempo em que ocupa o centro das atenções, tendo os alunos em atitude convergente para

\footnotetext{
9 "No final dos anos 50 e início de 60, o panorama do ensino de Química nas escolas secundárias oficiais do Estado de São Paulo, tomou novo colorido, se olharmos para o espaço extraclasse. Embora dentro do programa regular os professores esporadicamente utilizassem o laboratório, foram despontando, através das cadeiras de Química, tanto na capital como no interior, clubes de ciências, jornais científicos, sessões de filmes científicos, movimento que teve grande influência do Instituto Brasileiro de Educação Ciência e Cultura (lbecc), seção paulista. Este Instituto dentro da meta de introduzir a experimentação no ensino da área de Ciências lançou kits (laboratórios portáteis), roteiros avulsos de experiências para professores e alunos, publicou a revista Cultus, incentivou a criação de clubes de Ciências e, posteriormente, de feiras de Ciências" (Sicca, 1996, p. 119).

${ }^{10}$ A respeito do papel estratégico que o ensino de ciências experimentais e matemática passou a ocupar na esfera política internacional nos anos que sucederam a Segunda Guerra Mundial no contexto da Guerra Fria, inclusive no Brasil, ver Ortiz (2003a, 2003b); Dias (2008). 
ela, as mangas e o decote cavados, o cabelo curto e a ausência evidente de enfeites brinco, colar, etc. - sugerem uma condição de relativa neutralidade. O professor é importante porque coordena a atividade, regula o processo pedagógico e conduz a aprendizagem, mas sua importância se materializa sob a forma de anteparo neutro e substrato discreto para a ação didática que coloca o conteúdo no centro da ação pedagógica.

O centro da imagem é ocupado por nove alunas e alunos, dos quais duas olham atentamente para ela, enquanto os demais olham para o material que está sobre a mesa. De quatro deles se vê apenas o topo da cabeça ou algum fragmento do rosto, cinco estão mais centralizados e mais visíveis, sendo possível observar que nenhum usa uniforme. A performance deles é mais heterogênea que a do grupo da foto anterior. Os rapazes usam o cabelo com mais volume, sem fixador. O que está na frente, bem à direita da foto, usa uma franja bem penteada para o lado, e o que aparece vagamente atrás dele tem o cabelo um pouco volumoso, quase com topete. As meninas usam cabelos curtos, ainda que se observe que algumas os têm presos, duas os têm arrumados e uma, a que está bem na frente da professora, o usa solto e sem nenhum tipo de arranjo. Nenhuma delas chega a ser despojada, embora os modelos das roupas pareçam simples. Nenhuma parece usar maquiagem, mas é possível notar, na que está bem à frente da professora e na que aparece apenas o rosto, atrás, à esquerda, que usam as sobrancelhas feitas.

Há uma serenidade sugerida no aparente clima de agradável convivência entre estudantes e professora. Ao mostrar essa imagem são valorizados aspectos de civilidade e hierarquia, muito valorizados ao longo da década de 1950 e, evidentemente, reiterados nesse ano de 1960. Todos os alunos aparecem com as mãos postas e seguras, indicando algo de continência ou expectativa. Apesar disso, há certa concepção de estética juvenil escolar sendo celebrada na qual já podemos vislumbrar certos traços de despojamento e liberdade que serão característicos da década de 1960. Os cabelos estão soltos - mais longos e com menos fixador, tanto nos rapazes quanto nas moças - e as roupas misturam elementos de diferentes estilos - um laço frouxo, um estilo camponesa, golas variadas -, denotando traços de uma crescente experimentação individual. Uma das alunas usa uma vistosa pulseira, mas nenhuma traz unhas pintadas.

A cena retrata alguns elementos de disciplina e civilidade que caracterizam o mundo moderno, bastante inspirado na realidade que nos chegava pelos magazines e pelo cinema, mas também insinua muito sutilmente traços do protagonismo juvenil - a variedade e a diversidade de estilos - e da construção de uma imagem mais informal nas jovens: os cabelos em certo desalinho, por exemplo.

\section{Algumas considerações finais}

Evidentemente não se trata de pretendermos um delineamento conclusivo mas tãosomente tecer algumas considerações que possam corroborar nossas premissas iniciais e expandir um pouco a perspectiva de análise.

Para iniciar esta última secção começamos retomando o mote do nosso objeto principal, a Revista Atualidades Pedagógicas. Seu propósito, como já mencionado e como fica bastante evidente pelo seu título, é apresentar atualidades pedagógicas, ou seja, proporcionar ao leitor acesso a conteúdos, propostas e opiniões atuais. O que é essa atualidade? Trata-se de um conjunto de elementos que se pretende coincidente com o 
próprio tempo, seja sob a forma de divulgação de conteúdos que os editores consideram representativos de certa época e, portanto, mereciam receber destaque editorial e circular no meio pedagógico brasileiro, seja sob a forma de posições ou propostas consideradas inovadoras que os editores pretendiam que fossem disseminadas. Os doze anos de publicação da revista (1950-1962) coincidem, em certa medida, com o período de emergência das tendências modernizadoras ${ }^{11}$ e tecnicistas na escola brasileira. 0 tecnicismo, de acordo com uma classificação bastante usual (Saviani, 1983), corresponde à tendência que, baseada nos supostos da neutralidade científica e de uma forma elaborada de racionalidade, eficiência e produtividade, propõe a organização do trabalho educativo de modo a torná-lo objetivo e operacional. O centro da ação pedagógica é, principalmente, a organização racional dos meios e recursos didáticos,

ocupando professor e aluno posição secundária, relegados que são à condição de executores de um processo cuja concepção, planejamento, coordenação e controle ficam a cargo de especialistas supostamente habilitados, neutros, objetivos, imparciais. A organização do processo converte-se na garantia da eficiência, compensando e corrigindo as deficiências do professor e maximizando os efeitos de sua intervenção. (Saviani, 1983, p. 24)

As imagens apresentadas têm em comum alguns traços dessa tendência, já evidenciados na análise realizada na secção anterior: o uso de aparatos como o álbum seriado, a simultaneidade de fontes e a ênfase na memorização - no caso da primeira imagem - e o uso de laboratórios, a demonstração e o manuseio de materiais didáticos e a prática experimental - no caso da segunda imagem - são indicadores dessa tendência, em dois momentos da história da educação escolar brasileira. A diferença ${ }^{12}$ evidente entre as duas cenas, no que se refere ao procedimento didático, é que na primeira imagem a aula é demonstrativa e expositiva, tendo por base a memorização, tanto da professora, quanto dos alunos, enquanto que na segunda imagem a aula é demonstrativa e participativa, tendo por base a experimentação e o manuseio de material didático e jogos pedagógicos.

Em ambas verifica-se a centralidade do conteúdo mediado pelo uso especializado de recursos e técnicas. Em ambos os casos a professora se neutraliza, assumindo o lugar daquele que maneja ou manipula os recursos para transmitir o conteúdo. Um sinal que consideramos mais do que mera coincidência é o fato de ambas as professoras usarem

${ }^{11} \mathrm{O}$ debate a respeito do conceito moderno é bastante mais amplo e tem sido objeto de importante análise na historiografia onde, por exemplo, se discute as relações entre o par moderno/tradicional (Le Goff, 1987) e as tensões advindas daquilo que a certa altura figura como moderno e inovador, e em um momento seguinte pode se configurar como tradicional e antigo. Neste trabalho não vamos nos ater a tal debate, mas apenas reiterar que "todas as sociedades têm a sua própria modernidade e todas se consideram modernas, pelo menos devido ao facto de, na sua época, serem as mais recentes. Podemos aliás identificar, no passado das mais arcaicas sociedades e civilizações, marcas indiscutíveis de representações do mundo e de comportamentos modernos, quase sempre em conflito com o pensamento tradicional" (Rodrigues, 1994, p. 60).

12 Reconhecemos que há distinções importantes entre as imagens que analisamos: para além de terem uma distância temporal, se referem a disciplinas escolares distintas que merecem, ainda que não o façamos nesta ocasião, uma análise mais detalhada. Tanto a geografia, quanto a matemática possuem historiografias que se ocupam de suas práticas pedagógicas específicas, considerando aspectos sobre os quais não nos detivemos aqui. Para aprofundar investigações sobre a história das disciplinas escolares em suas práticas cotidianas ver Chervel (1990), Julia (2001).

\begin{tabular}{|l|c|c|c|c|c|}
\hline Hist. Educ. (Online) & Porto Alegre & v. 20 & n. 49 & Maio/ago., 2016 & p. 187-208
\end{tabular}


vestidos com as mangas cavadas. Ainda que essa condição seja, por si mesmo, um estilo, a ausência de mangas pode significar a supressão de um traço distintivo na indumentária da professora. No caso da primeira, apesar do vestido ter gola, aparecer com abotoamento e ser acinturado, a cor branca reforça a ideia da assepsia, da limpeza e da neutralidade. No caso da segunda, apesar de não ser possível ver muitos detalhes, a cor neutra e a ausência também de decote sugerem essa condição de neutralidade, especialmente, se contrapostas à variedade de elementos presentes nas roupas das alunas.

No que se refere aos estudantes fica patente a diferença entre as duas imagens. Enquanto na primeira se destaca a atmosfera formal - uso de uniforme, uso de terno, cabelos curtos e alinhados, corpos em postura mais rígida -, na segunda se destaca a crescente informalidade: cabelos soltos e com algum desalinho, ausência de uniforme, variedade de estilos e corpos mais descontraídos. O sentido de atualidade da estética juvenil parece-nos que está aproximada dos movimentos culturais dos dois momentos: se em 1955 predominava certa indiferenciação do jovem, assemelhando-se ao adulto e aderindo a uma postura mais formal, em 1960 já percebemos traços da diferenciação que levou aos movimentos de da juventude em suas manifestações culturais, singularidade da moda e estilo e revoluções nos valores tão característicos das décadas subsequentes.

Enfim, se consideramos que a escola é um dos mais potentes dispositivos civilizatórios que conhecemos, ao analisar as imagens acima podemos observar que, ao lado do cumprimento das tarefas curriculares pertinentes à instrução, a escola trata de oferecer uma série de parâmetros para a formação geral do sujeito: são princípios morais, valores, processos de socialização, estilos, formas de sensibilidade, exemplares de gosto. De modo conclusivo, podemos reiterar a ideia de que a escola, a partir da modernidade, assumiu a tarefa de formar ética e esteticamente o sujeito, proporcionando-lhe acesso a argumentos e estratégias para que seja capaz de praticar juízos de toda ordem em seu cotidiano. Sem pretender esgotar o tema, podemos afirmar que a escola tem proporcionado condições para que o sujeito conheça o mundo e aja sobre si mesmo de maneira a dirigir sua própria existência. Como já afirmamos no começo deste texto, o projeto civilizatório da escola moderna é pautado pela perspectiva da harmonia social, onde o todos é o parâmetro para o cada um e o padrão da cortesia, da conduta correta e adequada vai sendo transformado no ideal de civilidade.

Enxergamos, pela análise das capas escolhidas, a Revista Atualidades Pedagógicas como um vetor estetizante dessa expectativa, do que se pretendia que fosse a escola e a juventude naqueles anos.

\section{Referências}

A PRIMEIRA MISSA NO BRASIL. Disponível em <http://www.mnba.gov.br>. Acesso em 13 fev. 2013.

ARFUCH, Leonor. Las subjetividades en la era de la imagen: de la responsabilidad de la mirada. In: DUSSEL, Inés; GUTIERREZ, Daniela (comps.). Educar la mirada. Buenos Aires: Manatial/Flacso, 2006, p. 75-84.

BARROS, Myrian Moraes Lins de. Memória e família. Estudos Históricos. Rio de Janeiro, v. 2, n. 3, 1989, p. 29-42.

BARTHES, Roland. A câmara clara. Rio de Janeiro: Nova Fronteira, 1984. 
BASTOS, Maria Helena Câmara. A imprensa periódica educacional no Brasil (1808-1944). In: CATANI, Denice Bárbara; BASTOS, Maria Helena Câmara (org.). Educação em revista: a imprensa periódica e a história da educação. São Paulo: Escrituras, 1997, p. 173-187.

BERGER, John. Modos de ver. Rio de Janeiro: Rocco, 1999.

BURKE, Peter. Testemunha ocular. Bauru: Edusc, 2004.

BOTO, Carlota. A racionalidade escolar como processo civilizador: a moral que captura almas. Revista Portuguesa de Educação, Minho, v. 23, n. 2, 2010, p. 35-72.

CARVALHO, Vânia Carneiro de et al. Fotografia e história: um ensaio bibliográfico. Anais do Museu Paulista, v. 2, n. 1, 1994, p. 253-300.

CARVALHO, Vânia Carneiro de; LIMA, Solange Ferraz de. Fotografias como objeto de coleção e de conhecimento. Anais do Museu Histórico Nacional, v. 32, 2000, p. 15-32.

CASTROGIOVANNI, Antônio Carlos (org.). Ensino de geografia: práticas e textualizações no cotidiano. Porto Alegre: Mediação, 2000.

CATANI, Denice Bárbara; BASTOS, Maria Helena Camara (org.). Educação em revista: a imprensa periódica e a história da educação. São Paulo: Escrituras, 1997.

CHERVEL, André. História das disciplinas escolares: reflexões sobre um campo de pesquisa. Teoria \& Educação, Porto Alegre, n. 2, 1990, p. 177-229.

COLEÇÃO Brasiliana. Disponível em <http://www.brasiliana.com.br/brasiliana/colecao>. Acesso em 13 fev. 2013.

COUTINHO, Iluska. Leitura e análise da imagem. In: DUARTE, Jorge; BARROS, Antonio (orgs.). Métodos e técnicas de pesquisa em comunicação. São Paulo, Atlas, 2006, p. 330344.

DIAS, André Luis Mattedi. O movimento da matemática moderna: uma rede internacional científico-pedagógica no período da guerra fria. JORNADAS LATINO-AMERICANAS DE ESTUDOS SOCIAIS DAS CIÊNCIAS E DAS TECNOLOGIAS, 2008. Anais... Rio de Janeiro: Núcleo de Computação Eletrônica da UFRJ, 2008.

EAGLETON, Terry. A ideologia da estética. Rio de Janeiro: Zahar, 1993.

ELLSWORTH, Elizabeth. Modos de endereçamento: uma coisa de cinema; uma coisa de educação também. In: SILVA, Tomaz Tadeu da. Nunca fomos humanos: nos rastros do sujeito. Belo Horizonte: Autêntica, 2001, p.7-75.

ÊNIO Silveira (1925-1996). Disponível em <http://www.itaucultural.org.br/aplicexternas/ enciclopedia lit/index.cfm?fuseaction=biografias texto\&cd verbete=9348>. Acesso em 13 fev. 2013.

FRANCASTEL, Pierre. Imagem, visão e imaginação. Lisboa: Edições 70, 1983.

HALLEWELL, Laurence. O livro no Brasil: sua história. São Paulo: USP, 2005.

JOLY, Martine. Introdução à análise da imagem. Campinas: Papirus, 1996.

JULIA, Dominique. A cultura escolar como objeto histórico. Revista Brasileira de História da Educação, Campinas, n. 1, 2001, p. 9-43.

KOSSOY, Boris. A fotografia como fonte histórica. São Paulo: Museu da Indústria, Comércio e Tecnologia de São Paulo, 1980.

LE GOFF, Jacques. Antigo/moderno. In: ENCICLOPÉDIA EINAUDI. Lisboa: Imprensa Nacional; Casa da Moeda, 1987, v. 1 - Memória-História, p. 370-392. 
LEITE, Miriam Moreira. Retratos de família, São Paulo: USP, 1993.

LUCA, Tânia Regina de. História dos, nos e por meios dos periódicos. PINSKY, Carla Bassanezi (org.). Fontes históricas: fontes impressas. São Paulo: Contexto, 2005, p. 111153.

MANINI, Miriam. Análise documentária de fotografias: um referencial de leitura de imagens fotográficas para fins documentários. São Paulo: USP, 2002. 226f. Tese (doutorado em Ciências e Comunicação). Escola de Comunicações e Artes, Universidade de São Paulo, 2002.

MARANHÃO, Jorge. A arte da publicidade: estética, crítica e kitsch. Campinas: Papirus, 1988.

MARTÍN-BARBERO, Jesús; REY, Gonzalo. Os exercícios do ver. São Paulo: Senac, 2001.

MARTINS, Raimundo. A cultura visual e a construção social da arte, da imagem e das práticas do ver. In: OLIVEIRA, Marilda Oliveira de (org.). Arte, educação e cultura. Santa Maria: UFSM, 2007, p. 19-40.

MAUAD, Ana Maria. Através da imagem: fotografia e história, interfaces. Tempo, v. 1, n.2, 1996.

MAUAD, Ana Maria. Sob o signo da imagem: a produção da fotografia e o controle dos códigos de representação social pela classe dominante no Rio de Janeiro, na primeira metade do século XX. Niterói: UFF, 1990. 340f. Tese (doutorado em História Social). Programa de Pós-Graduação em História Social, Universidade Federal Fluminense.

MAUAD, Ana Maria. Usos e funções da fotografia pública no conhecimento histórico escolar. Hist. Educ. (Online), Porto Alegre, v.19, n. 47, 2015, p. 81-108.

MONTEIRO, Charles (org.). Fotografia, história e cultura visual: pesquisas recentes. Porto Alegre: PUCRS, 2012.

NARDI, Roberto. A área de ensino de ciências no Brasil: fatores que determinaram sua constituição e suas características segundo pesquisadores brasileiros. In: NARDI, Roberto (org.). A pesquisa no ensino de ciências no Brasil: alguns recortes. São Paulo: Escrituras, 2007, p. 357-412.

NEIVA JR, Eduardo. A imagem. São Paulo: Ática, 1986.

OBREGON, Javier Sáenz. La escuela como dispositivo estético. In: FRIGERIO, Graciela y DIKER, Gabriela (comp.). Educar: (sobre)impresiones estéticas. Buenos Aires: Del Estante, 2007, p. 73-86.

ORTIZ, Eduardo. La política interamericana de Roosevelt: George D. Birkhoff y la inclusión de América Latina en las redes matemáticas internacionales (Parte I). Saber y tiempo. Buenos Aires, v. 4, n. 15, 2003a, p. 53-111.

ORTIZ, Eduardo. El viaje de Birkhoff a la Argentina y la política interamericana de Roosevelt. Saber y tiempo. Buenos Aires, v. 4, n. 16, 2003b, p. 21-70.

PAIVA, Eduardo França. História \& imagens. Belo Horizonte: Autêntica, 2006.

PEREIRA, Marcos Villela. Estetização, escola e sensibilização moral. In: MEIRA, Mirela Ribeiro; SILVA, Úrsula Rosa da (orgs.). Ensino de arte: cultura visual, escola e cotidiano. Pelotas: Universitária, 2012a, p. 37-48.

PEREIRA, Marcos Villela. O limiar da experiência estética: contribuições para pensar um percurso de subjetivação. Pro-Posições, v. 23, n. 1, 2012b, p. 183-195. 
REVISTA ATUALIDADES PEDAGÓGICAS. São Paulo: Companhia Editora Nacional, $\mathrm{n}$. 1-54, 1950-1962.

RIOS, Diogo Franco. Memórias de ex-alunos do Colégio de Aplicação da Universidade da Bahia sobre o ensino de matemática moderna: a construção de uma instituição modernizadora. Salvador: UFBA, 2012. 504f. Tese (doutorado em Ensino, Filosofia e História das Ciências). Universidade Federal da Bahia.

RODRIGUES, Adriano Duarte. Comunicação e cultura: a experiência cultural na era da informação. Lisboa: Presença, 1994.

SAVIANI, Dermeval. Escola e democracia. Campinas: Autores Associados, 1983.

SICCA, Natalina Aparecida Laguna. Razões históricas para uma nova concepção de laboratório no ensino médio de química. Paideia. Ribeirão Preto, v. 10/11, 1996, p. 115129.

SMIT, Johanna. Propostas para a indexação de informação iconográfica. CONGRESSO INTERNACIONAL DE INFORMÁTICA, 1997. Actas... Havana: Info, 1997.

SOUZA, Tânia Clemente. A análise do não-verbal e os usos da imagem nos meios de comunicação. Rua, Campinas: Unicamp, v. 7, 2001, p. 65-94.

WELSCH, Wolfgang. Estetização e estetização profunda: a respeito da atualidade do estético nos dias de hoje. Porto Arte, Porto Alegre, v.6, n. 9, 1995, p. 7-22.

MARCOS VILLELA PEREIRA é professor na Pontifícia Universidade Católica do Rio Grande do Sul, doutor em Educação pela Pontifícia Universidade Católica de São Paulo. É bolsista produtividade em pesquisa do CNPq e atua nos cursos de graduação e pós-graduação em Educação, com ênfase nos fundamentos da educação.

Endereço: Avenida Ipiranga, 6681 - prédio 15 - sala 361 - 90619-900 - Porto Alegre - RS - Brasil.

E-mail: marcos.villela@pucrs.br.

DIOGO FRANCO RIOS é professor na Universidade Federal de Pelotas, doutor em Ensino, Filosofia e História das Ciências pela Universidade Federal da Bahia/Universidade Estadual de Feira de Santana. Atua no curso de licenciatura em Matemática e nos programas de pós-graduação em Educação Matemática e em Ensino de Ciências e Matemática, ambos da UFPel. Endereço: UFPel - Departamento de Educação Matemática - prédio 5 - sala 302 96160-990 - Capão do Leão - RS - Brasil.

E-mail: riosdf@hotmail.com.

Recebido em 9 de setembro de 2015.

Aceito em 13 de janeiro de 2016. 